\title{
Neuroenhancement in Healthy Adults, Part I: Pharmaceutical Cognitive Enhancement: A Systematic Review
}

Fond $\mathbf{G}^{1,2^{\star}}$, Micoulaud-Franchi $\mathrm{JA}^{3}$, Macgregor $\mathbf{A}^{2}$, Richieri $\mathbf{R}^{3,4}$, Miot $\mathbf{S}^{5,6}$, Lopez $\mathbf{R}^{2}, \mathbf{A b b a r} \mathbf{M}^{7}$, Lancon $\mathbf{C}^{3}$ and Repantis $\mathrm{D}^{8}$

${ }^{1}$ Université Paris Est-Créteil, Psychiatry and Addiction Pole University Hospitals Henri Mondor, Inserm U955, Eq 15 Psychiatric Genetics, DHU Pe-psy, FondaMental Foundation, Scientific Cooperation Foundation Mental Health, National Network of Schizophrenia Expert Centers, F-94000, France

${ }^{2}$ Inserm 1061, University Psychiatry Service, University of Montpellier 1, CHU Montpellier F-34000, France

${ }^{3}$ POLE Academic Psychiatry, CHU Sainte-Marguerite, F-13274 Marseille, Cedex 09, France

${ }^{4}$ Public Health Laboratory, Faculty of Medicine, EA 3279, F-13385 Marseille, Cedex 05, France

5Inserm U1061, Idiopathic Hypersomnia Narcolepsy National Reference Centre, Unit of sleep disorders, University of Montpellier 1, CHU Montpellier F-34000, Paris, France

6Inserm U952, CNRS UMR 7224, Pierre and Marie Curie University, F-75000, Paris, France

${ }^{7} \mathrm{CHU}$ Carémeau, University of Nîmes, Nîmes, F-31000, France

${ }^{8}$ Department of Psychiatry, Charité-Universitätsmedizin Berlin, Campus Benjamin Franklin, Eschenallee 3, 14050 Berlin, Germany

*Corresponding author: Dr. Guillaume Fond, Pole de Psychiatrie, Hôpital A. Chenevier, 40 rue de Mesly, Créteil F-94010, France, Tel: (33)178682372; Fax: (33)178682381; E-mail: guillaume.fond@gmail.com

Received date: January 06, 2015, Accepted date: February 23, 2015, Published date: February 28, 2015

Copyright: (c) 2015 Fond G, et al. This is an open-access article distributed under the terms of the Creative Commons Attribution License, which permits unrestricted use, distribution, and reproduction in any medium, provided the original author and source are credited.

\begin{abstract}
The term neuroenhancement refers to improvement in the cognitive, emotional and motivational functions of healthy individuals through inter alia, the use of drugs. This popular topic attracts attention both from the general public and the scientific community. Our objective is to summarize in a synthetic review the data of randomized placebo-controlled trials that assessed cognitive effects of administration of neuroenhancers in non-sleep-deprived healthy adults compared to placebo. The major outcomes were attention, memory, learning, executive functions, and vigilance/wakefulness. Details on the pharmacological profile, effectiveness and safety for each drug are provided. We classify them according to their recognized major primary mode of action, namely catecholaminergics (methylphenidate, modafinil, amphetamines, tolcapone, pramipexole, guanfacine, antidepressants), cholinergics (nicotine, varenicline, acetylcholine esterase inhibitors, anticholinergics), glutamatergics (ampakines, memantine, Dcycloserine), histaminergics, and non-specified (caffeine, racetams/phosphodiesterase inhibitors and glucocorticoids).
\end{abstract}

Keywords: Neuroenhancement; Cognitive performance; Memory; Attention; Healthy adult; Methylphenidate; Amphetamine; Modafinil

\section{Background}

The term "neuroenhancement" refers to improvements in the cognitive, emotional and motivational functions of healthy individuals through inter alia, the use of drugs. The latter phenomenon is usually called pharmaceutical neuroenhancement. Other terms that have been used to describe these particular substances when used in this context are "cognitive enhancers", "smart drugs", "memory enhancing drugs" and "nootropic drugs" (from the Greek root noos for mind and tropein for toward) [1]. A cognitive enhancer is a drug that positively impacts cognitive functions skills, namely memory, attention, learning, executive functions or vigilance. Psychostimulants are a particular class of drugs that are putatively widely used as cognitive enhancers, while the so-called nootropics are drugs that are thought to have specific neuroprotective effects, without causing sedation or stimulation. Neuroenhancement is a popular topic, attracting attention both from the general public and the scientific community $[2,3]$.

Prescription stimulants such as methylphenidate (MPH) and amphetamines are supposed to be the most frequently consumed smart drugs, especially in college campuses where, depending on the survey, 5 to $35 \%$ of healthy students reported having consumed them for neuroenhancement purposes in the past year (for a meta-analysis of the surveys [4]). However, this use is not limited to students since $\mathrm{MPH}$ is also used in professions involving high cognitive performances and wakefulness such as surgeons [5].

While placebo controlled trials support some of the claimed benefits for certain neuroenhancers, it is worth noting that not all of the claims have been formally tested. Further, major concerns are adverse effects, toxicity and the addiction potential, especially because these drugs are often consumed without medical follow-up and in some cases for a long-term. A useful debate about concerns on memory enhancement is documented [6]. In summary, different memory neural networks may be intertwined with a physiological optimal adjustment and modifying some parameters may put out of order the whole system. Pharmaceutical cognitive enhancement has the potential to become a major public health concern. Recent literature focuses mostly on the ethical debate rather than proof of effectiveness while on the other hand authors argue that research on efficacy and safety is or should be the rate-limiting step when considering the ethics of cognitive enhancement [7]. There are some systematic reviews and meta-analyses on certain drugs [8-10], but no 
Citation: Fond G, Micoulaud-Franchi JA, Macgregor A, Richieri R, Miot S, et al. (2015) Neuroenhancement in Healthy Adults, Part I: Pharmaceutical Cognitive Enhancement: A Systematic Review. J Clinic Res Bioeth 6: 213. doi:10.4172/2155-9627.1000213

Page 2 of 15

comprehensive and synthetic review is available on data concerning more than a few cognitive enhancers.

The objective of this study was to synthesize the effectiveness of the data of cognitive enhancers in healthy adults. The primary outcomes of our interest were memory, attention, learning, executive functions and vigilance/wakefulness.

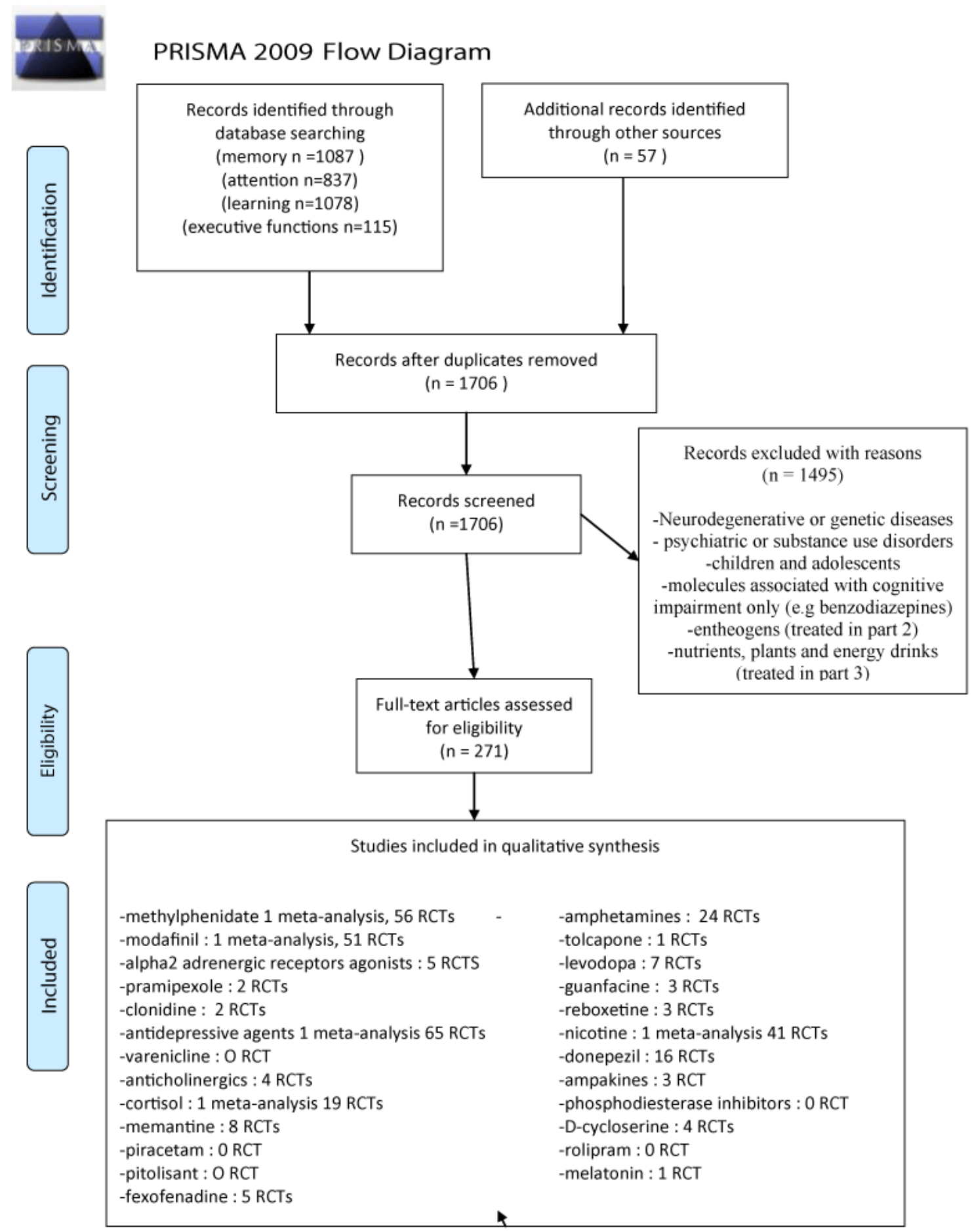

Figure 1: Representation of work flow followed in this study. 
Citation: Fond G, Micoulaud-Franchi JA, Macgregor A, Richieri R, Miot S, et al. (2015) Neuroenhancement in Healthy Adults, Part I: Pharmaceutical Cognitive Enhancement: A Systematic Review. J Clinic Res Bioeth 6: 213. doi:10.4172/2155-9627.1000213

Page 3 of 15

\section{Search Strategy and Selection Criteria}

\section{Types of interventions}

All randomized controlled trials (RCTs) with cognitive enhancers (which were not predefined) in all doses and dosing schedules (single dose or repeated doses) for any duration and by any route of administration in comparison with placebo were included.

\section{Population}

Individuals of 18 years or more age, in a normal state of wakefulness, who showed no evidence of psychiatric disorder, cognitive decline or other diseases, were considered.

\section{Search strategy}

A specific search strategy was developed for the interface PubMed (MEDLINE database), based on a combination of MeSH terms: "neuroenhancement" or "cognitive/cognition enhancement" OR "smart drug" as well as indexed terms related to cognitive functions such as "memory", "attention", "learning", "executive function", "vigilance", "wakefulness" and the words "controlled trial" and "placebo", "healthy". We searched Medline (1966-2014), Medline InProcess and other non-indexed citations (from 1966 to 2014), Embase (1980-2014), the Cumulative Index to Nursing and Allied Health Literature (1982-2014), PsycINFO (1806-2014), the Cochrane Library database (inception-2014), Biosis Previews (1926-2014), TOXNET database (inception-2014) and Web of Science (1975-2014). All relevant references were checked for additional and unpublished citations. We contacted pharmaceutical companies that market the molecules identified as potential neuroenhancers and authors of trials with incompletely reported data. All studies were assessed for meeting inclusion criteria (GF), and a second researcher reviewed those used for analysis (CL). Last search was conducted on May 5, 2014 (Figure $1)$.

Overall, 5 meta-analyses and 266 RCTs were included in the qualitative analysis. We classified the presented substances according to their recognized major primary mode of action. Acetylcholine, dopamine, glutamate, histamine and serotonin receptors have been reported to play a fundamental role in cognition [11]. Others like adenosine, cannabinoid, GABA, opioid and sigma receptors seemed to be involved but their role is less clear at the moment. Both receptoroperated and potential-operated ionic channels are also critically involved. Respectively, we report on catecholaminergic, cholinergic, glutamatergic and histaminergic drugs. Some substances exhibit mixed mechanisms of action. Racetams/phosphodiesterase inhibitors and glucocorticoids were presented separately.

\section{Catecholaminergics}

Catecholamines derive from the amino acid tyrosine. Until the 1950 's dopamine was thought to be nothing but part of the synthesis of norepinephrine and epinephrine. It was not until dopamine was found in the brain in the same levels as norepinephrine that it was considered that dopamine might have a biological role per se. Midbrain dopamine neurons are essential for controlling key functions of the brain, such as working memory. The largest populations of midbrain dopamine neurons are localized in two neighbouring nuclei, the substantia nigra and the ventral tegmental area [12].

Dopaminergics are defined as substances that affect the neurotransmitter dopamine or the components of the nervous system that use dopamine. Dopamine reuptake inhibitors (like amphetamines) have been shown to be effective in the regulation of appetite and food intake in obese individuals, however most of them have been withdrawn due to adverse side effects such as increase in blood pressure and high abuse potential [13].

\section{Methylphenidate}

Methylphenidate (MPH) (Ritalin ${ }^{\otimes}$ ) is a partial blocker of the dopamine transporter that enhances dopamine and norepinephrine release with pharmacologic mechanisms similar to those of amphetamines (by inhibiting dopamine reuptake in striatum). Methylphenidate is a psychostimulant drug that was first licensed by the US Food and Drug Administration (FDA) in 1955 for treating attention-deficit/hyperactivity disorder (AD/HD) in children [14]. It became heavily prescribed in the 1990s, when the number of AD/HD diagnoses raised.

As part of a recent systematic review [8] including 46 trials, several meta-analyses of studies that tested the effects of MPH were performed. It was found that a single dose of MPH (5 to $40 \mathrm{mg}$ or 0.25 to $0.5 \mathrm{mg} / \mathrm{kg}$ ) had a distinguishable effect in one outcome, namely memory: a large positive effect was shown (1.4; standard error $\mathrm{SE}=0.48, \mathrm{p}<0.007)$. No statistically significant effect was found in the outcomes attention and executive functions, while for wakefulness, the lack of baseline measurements did not allow for a statistical analysis. For a detailed analysis of methods and results of RCTs assessing MPH effect on cognitive performances in healthy subjects [8]. The major findings of additional RCTs that were conducted after Repantis et al. meta-analysis are summarized in Table 1 [15-25].

\section{Modafinil}

Modafinil (Provigil", Vigil ${ }^{\circ}$ ), a non-amphetamine wakefulnesspromoting agent, is a first-line pharmacological option for the treatment of excessive sleepiness associated with narcolepsy. Modafinil has low micromolar affinity for the dopamine transporter (DAT). Inhibition of dopamine reuptake via the DAT explains the enhancement of dopamine levels in several brain areas, an effect shared with psychostimulants like cocaine, methylphenidate, and the amphetamines [26]. Unlike amphetamines, which display widespread brain activation, modafinil has shown specificity for brain structures associated with wakefulness, including the posterior and lateral hypothalamus (tuberomammilary nucleus and orexin cells) [27]. Effects on glutamate, histamine and orexin/hypocretin have also been evocated $[28,29]$. There is increasing evidence that modafinil affects cortical function. This may be due to preferential effects of modafinil on the noradrenaline system, consistent with the well-established finding that noradrenaline receptors are abundant in the prefrontal cortex but are virtually absent from the striatum. 
Citation: Fond G, Micoulaud-Franchi JA, Macgregor A, Richieri R, Miot S, et al. (2015) Neuroenhancement in Healthy Adults, Part I: Pharmaceutical Cognitive Enhancement: A Systematic Review. J Clinic Res Bioeth 6: 213. doi:10.4172/2155-9627.1000213

Page 4 of 15

\begin{tabular}{|c|c|c|}
\hline & $\mathbf{N}$ & Major findings \\
\hline \multicolumn{3}{|l|}{ Catecholaminergics } \\
\hline Methylphenidate & 56 & $\begin{array}{l}\text { Strongest evidence in working memory enhancement, and weaker evidence in other memory domains } \\
\text { and attention. No evidence for vigilance improvement and some evidence for subjective improvement } \\
\text { of wakefulness reported by users. }\end{array}$ \\
\hline Modafinil & 51 & Moderate positive effect on attention. No evidence for memory or vigilance enhancement. \\
\hline Amphetamines & 24 & Strong positive effects on verbal learning, delayed memory, vigilance and inhibitory control. \\
\hline COMT inhibitor: Tolcapone & 3 & Enhancement of verbal episodic memory. \\
\hline Levo-DOPA & 7 & Some positive effects in encoding but no effect on memory and selective attention. \\
\hline Dopamine partial agonist: Pramipexole & 2 & No enhancement effect. \\
\hline Alpha2 adrenergics receptors agonists & 5 & No enhancement effect. \\
\hline $\begin{array}{l}\text { Serotoninergic and noradrenergic } \\
\text { antidepressive agents }\end{array}$ & 65 & No enhancement effect. \\
\hline Caffeine & $>20$ & $\begin{array}{l}\text { Possible small improvement of performance, but the major effect seems to be the reversal of the } \\
\text { withdrawal effects. }\end{array}$ \\
\hline \multicolumn{3}{|l|}{ Cholinergics } \\
\hline Nicotine & 41 & $\begin{array}{l}\text { Significant positive effects on fine motor, alerting attention, orienting attention, short-term episodic } \\
\text { memory and working memory performances. }\end{array}$ \\
\hline Varenicline & 0 & No data \\
\hline Donezepil & 12 & $\begin{array}{l}\text { Positive effect on procedural, verbal and spatial memory, information processing and some executive } \\
\text { function for single dose, but impairment effect or no effect on attention for repeated dose, especially in } \\
\text { older subjects. }\end{array}$ \\
\hline Anticholinergics & 4 & $\begin{array}{l}\text { Some data for episodic and verbal memory enhancement in the elderly in } 2 \text { RCT. Impairments effect } \\
\text { have been also described in } 2 \text { RCT. }\end{array}$ \\
\hline \multicolumn{3}{|l|}{ Glucocorticoids } \\
\hline Hydrocortisone & 19 & Enhancing or impairing effects depending on the time of administration. \\
\hline \multicolumn{3}{|l|}{ Glutamatergics } \\
\hline Ampakines (Farampator and Cx-516) & 4 & No enhancement effects. \\
\hline NMDA antagonists: Memantine & 7 & No enhancement effects of single-dose administration. \\
\hline NMDA agonists: D-Cycloserine & 4 & No clear memory enhancement effect. \\
\hline Racetams & 0 & No data \\
\hline Phosphodiesterase inhibitors & 0 & No data \\
\hline \multicolumn{3}{|l|}{ Histaminergics } \\
\hline $\begin{array}{l}\text { Histamine } \mathrm{H} 3 \text { receptor inverse } \text { agonist/ } \\
\text { antagonist: pitolisant }\end{array}$ & 0 & No data \\
\hline $\mathrm{H} 1$ antagonist fexofenadine & 5 & No attention or vigilance enhancement effect \\
\hline \multicolumn{3}{|l|}{ Melatoninergics } \\
\hline Melatonine & 1 & Positive effect on object recognition in one RCT. \\
\hline Agomelatine & 0 & No data \\
\hline
\end{tabular}

Table 1: Summary of randomised controlled trials (RCTs) on cognitive enhancement effects of current available substances, when given to healthy non sleep-deprived subjects. N: Number of RCTs included in our qualitative review (including RCTs included in meta-analyses). COMT: Catecholamine O-Methyl-Transferase. 
In a recent systematic review including 45 trials several metaanalyses of studies that tested the effects of modafinil were performed. A single dose of modafinil (100 to $400 \mathrm{mg}$ ) given to non-sleep deprived individuals was found to have a moderate, positive effect on attention $(0.56, \mathrm{SE}=0.27, \mathrm{p}<0.05)$ [8]. A meta-analysis of memory tasks did not reveal any significant effects. Statistical analysis on the effects on executive functions could not be performed due to the lack of numerical data for baseline measurements. Details on RCTs examining Modafinil's effect on cognitive performances in healthy subjects is reported [8]. The major findings of additional RCTs that were conducted after Repantis et al. meta-analysis are summarized in Table 1 [18,21,25,30-33]. Another recent meta-analysis with more stringent criteria (only 3 trials included) concluded to a relatively weak pooled effect of modafinil on some aspects of cognitive performance in normal, rested adults [34].

\section{Amphetamines}

Amphetamines (dexamphetamine, (Dexedrine ${ }^{\circ}$ ) and chemically related substances) have a long history of both medical and nonmedical use and abuse. Adderall is a combination of four amphetamine salts (racemic amphetamine aspartate monohydrate, racemic amphetamine sulfate, dextroamphetamine saccharide, and dextroamphetamine sulfate) [14]. Amphetamines are sympathomimetic amines with central nervous system (CNS) stimulant activity that have both therapeutic properties and a potential for abuse. Amphetamines are considered as dopamine transporter substrates and as dopamine releasers, acting, mostly on the dopamine vesicle transporter VMAT2 and releasing dopamine in the extracellular cleft by reversing the direction of the transport of dopamine [35]. The pharmacological effects of amphetamines have been attributed to their effects on central catecholamine neurotransmission, where they block the reuptake from the synapse, inhibit the action of monoamine oxidase and facilitate the release of dopamine and norepinephrine [36,37]. Although it was thought that amphetamine use for non-medical reasons was more widespread in the US but less so in Europe, there has been a recent cross-sectional study showing that in France amphetamines were used as frequent as MPH by medicine and pharmacology students for neuroenhancement purposes [38].

The first review on the effects of amphetamine's on performance of healthy individuals was published in 1962 and concluded that $10 \mathrm{mg}$ $\mathrm{d}$-amphetamine may hasten conditioning, increase the rate at which subjects may acquire proficiency in a motor skill, decrease discriminative reaction time (but more in fatigued subject than in others), improve coordination performances but do not improve strictly speaking intellectual performance [39]. Since this work, more than 40 RCTs assessing cognitive performance of healthy adults after amphetamine administration have been conducted; about half of them focusing on mood enhancement. Studies assessing d-amphetamine and methamphetamine's effect on cognitive performances in nonsleep deprived healthy adults are summarized in Table 1 [40-61]. Surprisingly no meta-analysis of this data has been carried out to date. In summary, a large number of studies found a large positive effect of a $\mathrm{d}$-amphetamine single dose administration in verbal memory tasks, on vigilance, learning and inhibitory control and on delayed memory rather than immediate/short term memory (Table 1) but negative results were also reported [47] and a meta-analysis is warranted to determine the effectiveness of amphetamine administration on cognitive performances in healthy adults.

\section{Catecholamine-O-Methyl transferase inhibitor: tolcapone}

Tolcapone (Tasmar) is a CNS specific catecholamine-Omethyltransferase (COMT) inhibitor. It is indicated for the treatment of Parkinson's disease [14] and was introduced into the European market in 1997 and subsequently into the United States market in 1998.

Tolcapone (200 mg single dose) has been found to significantly improve executive function and verbal episodic memory performances in healthy adults $[62,63]$. Tolcapone $100 \mathrm{mg}$ three time a day for 1 day and $200 \mathrm{mg}$ three times a day for 6 days showed no modification of performance during a variable attentional control task [64].

\section{Levodopa (L-DOPA)}

L-DOPA (L-3,4-dihydroxyphenylalanine) (Sinemet, Parcopa , Atamet ${ }^{\circ}$, Stalevo ${ }^{\circ}$, Madopar', Prolopa ${ }^{\circ}$ ) is in some animals and humans a product of biosynthesis deriving from the amino acid L-tyrosine. LDOPA is the precursor to the neurotransmitters dopamine, norepinephrine and epinephrine. As a drug, it is used in the treatment of Parkinson's disease and dopamine-responsive dystonia.

The results of the 7 studies that were found on L-DOPA effects on memory and attention are summarized in Table 1. L-DOPA seems to improve encoding but showed no effect on long-term memory and selective attention [65-71].

\section{Dopamine partial agonist: pramipexole}

Pramipexole (Mirapex, Mirapexin', Sifrol ${ }^{\circ}$ ) is a partial/full receptor agonist for dopamine receptors D2, D3 and D4, and has been viewed as the prototype for preferential D3 agonist.

Contrary to pharmacological expectations, a $0.5 \mathrm{mg}$ single dose pramipexole has been found to induce sleepiness in healthy subjects [72] and to impair reinforcement learning [73].

\section{Alpha2 adrenergics receptors agonists: guanfacine and clonidine}

Guanfacine (Tenex', Intuniv ${ }^{\circ}$ ) and clonidine (Kapvay', Nexiclon', Catapressan, Dixarit ${ }^{\circ}$ ) are $\alpha 2 \mathrm{~A}$ receptor agonists, indicated for the treatment of hypertension but also ADHD [14]. a2A receptors are concentrated heavily in the prefrontal cortex and the locus coeruleus and may be involved in attention networks.

Guanfacine and clonidine both increased visual paired associates learning in one trial [74]. In another trial, clonidine administration (150-300 $\mu \mathrm{g})$ was associated with subjective sedation and impaired performances (especially in attention) in 15 young adults [75]. Clonidine impaired working memory while inducing feelings of drunkenness, but did not alter the long-term formation of memories. Another study found no effect of guanfacine on healthy male adult's executive functions and working memory [76]. Guanfacine has also been found to influence emotional memory via modulation of the prefrontal cortex [77].

\section{Selective norepinephrin reuptake inhibitors}

The norepinephrine transporter (NET) is located in the plasma membrane of noradrenergic neurons, where it reuptakes released norepinephrine (NE). The NET thus serves as the primary mechanism for the inactivation of noradrenergic signaling. Only a very limited 
Citation: Fond G, Micoulaud-Franchi JA, Macgregor A, Richieri R, Miot S, et al. (2015) Neuroenhancement in Healthy Adults, Part I: Pharmaceutical Cognitive Enhancement: A Systematic Review. J Clinic Res Bioeth 6: 213. doi:10.4172/2155-9627.1000213

Page 6 of 15

number of NET-selective inhibitors are available to date. Reboxetine (Edronax", Norebox", Prolift, Solvex", Davedax" or Vestra ${ }^{\circ}$ ), a racemic mixture of the (R,R)- and (S,S)-enantiomers, was the first potent, selective and specific NE reuptake inhibitor and has been marketed as an antidepressant. Atomoxetine (Strattera ${ }^{\circ}$, Tomoxetin', Attentin ${ }^{\circ}$ ) is approved for the treatment of ADHD [14] and has been found to increase NE and dopamine levels by 3 fold in the prefrontal cortices of rats without modifying dopamine levels in the striatum or nucleus accumbens [78].

Contrary to expectations, reboxetine ( $8 \mathrm{mg}$ single dose) did not improve attention, memory or learning in healthy adults [79-81]. It has been suggested that a single dose is not sufficient for significant effectiveness on cognitive performances. A $60 \mathrm{mg}$ single dose atomoxetine improved response inhibition, but had no effect on probabilistic learning [82].

\section{Antidepressive agents}

Most of the antidepressive agents are serotoninergics. Serotonin, or 5-hydroxytryptamine (5-HT), is found to be involved in many physiological or pathophysiological processes including cognitive function. Seven distinct receptors (5-HT1-7), each with several subpopulations, have been identified for serotonin, which are different in terms of localization and downstream signalling [83]. Because of the development of selective agonists and antagonists for these receptors as well as transgenic animal models of cognitive disorders, our understanding of the role of serotonergic transmission in learning and memory has improved in recent years. A large body of evidence indicates the interplay between serotonergic transmission and other neurotransmitters including acetylcholine, dopamine, $\gamma$-aminobutyric acid (GABA) and glutamate, in the neurobiological control of learning and memory [83].

A recent systematic review [84] reported the results of 65 single dose trials of second-generation antidepressant drugs in healthy adults (namely bupropion, citalopram, duloxetine, escitalopram, fluoxetine, fluvoxamine, moclobemide, paroxetine, reboxetine, sertraline or venlafaxine). Additional data on bupropion, moclobemide and tianeptine are presented separately hereafter. After a single dose of an antidepressant, a significant negative effect was shown in wakefulness, and a positive effect in memory, the latter however being the result of only one study. There was no significant improvement in attention or executive functions. No consistent evidence for enhancing effects of repeated intake of antidepressants could be found, however there are only a few studies administrating antidepressants in healthy individuals for a longer period of time.

\section{Monoamine-oxidase inhibitors}

Moclobemide (Aurorix ${ }^{\oplus}$, Manerix $^{\infty}$ ) and befloxatone are reversible and selective monoamine oxidase A (MAO-A) inhibitors; this enzyme preferentially deaminates serotonin, melatonin, epinephrine, and norepinephrine. Dopamine is equally deaminated by MAO-A and B [85]. Milacemide is a MAO-B inhibitor and glycine a prodrug that has been studied for its effects on human memory and as a potential treatment for the symptoms of Alzheimer's disease. Tranylcypromin (Parnate $^{\oplus}$, Jatrosom ${ }^{\circledR}$ ) is a mixed MAO inhibitor.

Overall, $150 \mathrm{mg} / \mathrm{d}$ moclobemide given for 3 days $(\mathrm{N}=15)$ [86], 150 $\mathrm{mg} / \mathrm{d}$ moclobemide for 14 days $(\mathrm{N}=20)$ [87] and a single dose of befloxatone (20 mg, $\mathrm{N}=15$ ) [88] showed no significant cognitive effect.
Contrary to a preliminary encouraging study [89], milacemide (400 $\mathrm{mg}$, single dose) did not improve cognitive performance in healthy adults, and was even associated with decreases in some vigilance performances [90]. The research on this substance was discontinued afterwards. We found no RCT on tranylcypromine.

\section{Bupropion}

Bupropion (3-chloro-N-tert-butyl- $\beta$-ketoamphetamine, Wellbutrin, Zyban', Voxra, Budeprion', Prexaton", Elontril or Aplenzin") is a norepinephrine-dopamine reuptake inhibitor approved by the FDA for depression and tobacco smoking cessation [14]. Bupropion also acts as a nicotinic acetylcholine receptor antagonist [91].

A single dose of 150 to $300 \mathrm{mg}$ of bupropion had no effect on cognitive tasks [92-95]. One study found significant improvement on one attention task (a simple reaction time task) without increasing impulsivity [96]. One hundred and fifty $\mathrm{mg} / \mathrm{d}$ bupropion for 6 days followed by $300 \mathrm{mg} / \mathrm{d}$ for 8 days showed no significant cognitive improvement in 12 healthy adults compared to placebo [97].

\section{Tianeptine}

Tianeptine (Stablon', Coaxil', Tatinol') is an antidepressant that was discovered by The French Society of Medical Research in the 1960s. It has structural similarities to the tricyclic antidepressants, but different pharmacological properties. Tianeptine is a selective serotonin reuptake enhancer (SSRE), opposite to the action of selective serotonin reuptake inhibitors (SSRIs), which are more commonly used for the treatment of depression. Tianeptine and fluoxetine show opposite effects on serotonin reuptake in humans [98]. Another study/review suggests that long-term administration of tianeptine has no effect on serotonin pathways [99]. Tianeptine enhances the extracellular concentration of dopamine in the nucleus accumbens and modulates the D2 and D3 dopamine receptors, but this effect is modest and almost certainly indirect [100]. Tianeptine acts also on the NMDA and AMPA receptors [101]. A recent review points to this pathway as a hypothesized mechanism of action, based on tianeptine's effect of reversing impaired neuroplasticity associated with stress [99]. Like SSRIs, however, tianeptine's onset-of-action delay is approximately 2-6 weeks with improvements sometimes noticeable in as soon as one week [102]. Its short-lived, but pleasant, stimulant effect experienced by some patients is shared with its predecessor, amineptine, whose side effects related to dopamine uptake inhibitor activity resulted in research into tianeptine.

A single administration of a supratherapeutic single dose of tianeptine $(75 \mathrm{mg})$ did not induce significant psychostimulant effect on attention and vigilance in young healthy volunteers [103]. No RCT assessing tianeptine repeated-administration RCT in healthy adults was published to date.

\section{Cholinergics}

Cholinergics are substances that affect the neurotransmitter acetylcholine or the components of the nervous system that use acetylcholine. Cholinergic cognitive enhancers include acetylcholine precursors and cofactors, and acetylcholinesterase inhibitors. There are three major cholinergic subsystems in the brain, two of which are projection systems with broad, diffuse and rather sparse innervation to wide areas of the brain [104]. In these two projection systems, cholinergic neurons originate either from (i) basal forebrain nuclei from where they innervate mainly the cortex (e.g. neocortex, cingulate 
cortex) and hippocampus, or (ii) from brainstem from where they provide widespread innervation to the thalamus and midbrain dopaminergic areas [105]. The third cholinergic subsystem arises from a collection of cholinergic interneurons in the striatum, which provides very dense local innervation. These interneurons contribute about $1-3 \%$ of the striatal neurons and interact with the rich dopaminergic innervation of the striatum [106].

The neurotransmitter acetylcholine (ACh) can regulate neuronal excitability throughout the nervous system via two types of receptors. The metabotropic G protein-coupled muscarinic ACh receptors (mAChRs) belong to the multigene family of serotonin, norepinephrine and dopamine receptors and play an important role for memory functions [106]. The ionotropic cys-loop ligand-gated nicotinic ACh receptor channels (nAChRs) are members of the supergen family that comprise glycine, GABA and 5HT-3 receptors and appear to be more relevant for attentional functions (particularly sustained attention) than muscarinic receptors, with stronger evidence pointing to the involvement of the a $4 \beta 2$ subtype [107]. The hippocampus is an important area in the brain for learning and memory, where both nAChRs and mAChRs are expressed [108-110].

After the publication of the cholinergic hypothesis of Alzheimer disease by Bartus et al. [111], tremendous efforts have been undertaken to find selective acetylcholine receptor agonists (and acetylcholinesterase inhibitors) to counteract cholinergic dysfunction. The search started with M1 mAChR agonists, was continued with efforts to find selective presynaptic M2 receptor antagonists, shifted later to nicotinic acetylcholine (partial) agonists and since 2002 came back to allosteric M1 mAChR agonists [112]. For a review of cholinergic drugs in development, see [112].

\section{Nicotine}

Nicotine is a potent parasympathomimetic alkaloid found in the nightshade family of plants (Solanaceae). It acts as a nicotinic acetylcholine receptor agonist. Nicotine is named after the tobacco plant Nicotiana tabacum, which in turn is named after the French ambassador in Portugal, Jean Nicot de Villemain, who sent tobacco and seeds to Paris in 1560, and who promoted their medicinal use. The cholinergic modulation of the midbrain dopamine system has been connected to nicotine self-administration in rats and hence is thought to support drug reinforcement [113].

Nicotine is likely one of the most extensively studied drugs in humans and its effects on cognitive abilities have been extensively reviewed. A recent meta-analysis [10], including 41 RCTs on nicotine administration in healthy adults (non-smokers or not tobaccodeprived smokers) found significant positive effects of nicotine or smoking on six domains: fine motor, alerting attention-accuracy and response time (RT), orienting attention-RT, short-term episodic memory-accuracy, and working memory-RT (effect size range $=0.16$ to $0.44)$. The majority of studies (75\%) administered nicotine via a medication approved by the FDA, usually nicotine gum and transdermal patch. Most studies (73\%) administered single doses of nicotine. Nicotine has been also found to enhance driving [114] and flight [115] performances. For a detailed analysis of the methodologies and results of these studies see [10].

\section{Varenicline}

Varenicline (Chantix ${ }^{\circ}$, Champix $\left.^{\circ}\right)$ is a high-affinity partial agonist at $\alpha 4 \beta 2, \alpha 3 \beta 4, \alpha 3 \beta 2$ and $\alpha 6 \mathrm{nAchRs}$ (though with a somewhat lower affinity for the three last), and a full agonist at homomeric $\alpha 7$ receptors, for which it shows a lower affinity than for $\alpha 4 \beta 2$ receptors [116]. It was launched in 2006 as a treatment for tobacco cessation [14].

No RCT comparing cognitive enhancement potential properties of varenicline in non-smokers healthy adults or smokers without nicotine deprivation was published to date.

\section{Acetylcholine Esterase Inhibitors}

Donepezil (Aricept ${ }^{\circ}$ ), rivastigmine (Exelon $\left.{ }^{\circ}\right)$, galantamine (Nivalin ${ }^{\circ}$, Razadyne, Reminyl, Lycoremine'), and physostigmine (Antilirium, Eserine Salicylate, Isopto Eserine, and Eserine Sulfate ${ }^{\circ}$ ) are all acetylcholine esterase inhibitors (AChEIs) that enhance synaptic acetylcholine levels. Galantamine, an alkaloid extracted from the bulbs of the Amaryllidaceae family that include the common snowdrop, not only blocks AChE, but also acts as a positive allosteric modulator of nicotinic acetylcholine receptors enhancing the concentrations of acetylcholine in the brain by a further mechanism. AChEIs are approved for the treatment of patients with mild to moderate dementia due to Alzheimer's disease [14].

The effectiveness of donepezil in healthy adults cognitive performances has been recently reviewed [9]. In summary, RCTs with healthy individuals have been conducted mostly with donepezil $(5 \mathrm{mg}$ single dose or $5 \mathrm{mg} / \mathrm{d}$ ). A single dose of $5 \mathrm{mg}$ donepezil has been found to improve information processing $[117,118]$, procedural, verbal and visual spatial memory [119-121] and some executive functions [122]. A positive effect of donepezil was found in voluntary but not involuntary attention in one study [123]. Conflicting results were found concerning working memory $[118,124,125]$. Two studies found that repeated doses of donepezil $(5 \mathrm{mg} / \mathrm{d}$ during 30 days) improves episodic memory [126] and complex aviation skills [127,128] but three others found no effect or even impairment in memory, attention or executive functions especially in older subjects [129-131]. Physostigmine showed also a positive impact on working memory [132-134].

\section{Anticholinergics}

Biperiden (Akineton'), trihexyphenidyl (Artane Parkinane $\left.{ }^{\circ}\right)$ tropatepine (Lepticur ${ }^{\circ}$ ), are specific muscarinic M1 anticholinergic drugs approved as anti-parkinsonian drugs [14] .

Biperiden has been found to enhance episodic memory performance in healthy elderly subjects in one RCT [135]. Another trial found that $1-2 \mathrm{mg}$ trihexyphenidyl improved verbal memory in 24 healthy elderly [136]. In a third one however, biperiden $(4 \mathrm{mg})$ or trihexyphenidyl $(5 \mathrm{mg}$ ) were found to both decrease memory performances [137].

\section{Glutamatergics}

Glutamate is one of the main excitatory neurotransmitters and has a strong impact on synaptic plasticity, learning and memory. The overlap and convergence of both dopaminergic and glutamatergic projections in the brain provides a framework for complex neuronal interactions between these receptor systems [138]. Furthermore, recent evidence identified the endogenous cholinergic signalling via nicotinic acetylcholine receptors (nAChRs) as key players in determining the morphological and functional maturation of the glutamatergic system [139]. Glutamatergic AMPA receptors are 
thought to contribute to information transmission between neurons, whereas NMDA receptors are mainly considered to be coincidence detectors that activate after multiple previous depolarizations. The NMDA receptor activation subsequently leads to a long-lasting increase in synaptic AMPA receptor availability and synaptic potentiation [140].

\section{Ampakines}

The ampakines take their name from the glutamatergic AMPA receptor, with which they strongly interact. The AMPA receptor, in turn, gets its name from AMPA (2-amino-3-(3-hydroxy-5-methylisoxazol-4-yl) propanoic acid), which selectively binds to it and mimics the effect of glutamate. Ampakines are a class of compounds known to enhance attention span and alertness, and facilitate learning and memory in animals [141]. Their action is theorized to be due to facilitation of transmission at cortical synapses that use glutamate as neurotransmitter. This in turn may promote plasticity at the synapse, which could translate into better cognitive performance. Some members of the ampakine family of drugs may also increase levels of trophic factors such as brain-derived neurotrophic factor (BDNF). More recently developed ampakine compounds are much more potent and selective for the AMPA receptor; however none of the newer selective ampakine compounds has reached the market yet [112].

Ampakines have been investigated by the Defense Advanced Research Projects Agency (DARPA), an agency of the United States Department of Defense responsible for the development of new technologies for use by the military. Preliminary results were disappointing. Farampator (500 mg single dose) improved short-term memory, but appeared also to impair episodic memory in 16 healthy elderly volunteers [142]. Another AMPA agonist, CX-516 (1(quinoxalin-6 ylcarbonyl)piperidine) (300 to $900 \mathrm{mg}$, single dose) was found to improve short-term delayed memory in 3 RCTs (respectively 24 and 50 healthy young individuals and 18 elderly individuals [143-145].

\section{NMDA antagonists: Memantine}

Memantine (Axura, Akatinol', Namenda', Ebixa', Abixa ${ }^{\circ}$, Memox $^{\circ}$ ) is the only one of a class of Alzheimer's disease medications acting on the glutamatergic system by blocking NMDA-type glutamate receptors. Memantine also binds to $\alpha 4 \beta 2$ and $\alpha 7 \mathrm{nAChRs,} \mathrm{and} \mathrm{to} \mathrm{5-}$ HT3 receptors [112]. It was synthesized in 1968 and was first launched in Germany in 1982. Despite years of research, there is little evidence of effect in mild dementia due to Alzheimer's disease [146], while it has positive effects in moderate to severe dementia for which it is also approved for use.

In a recent systematic review, 7 RCTs were included, in which 20-40 $\mathrm{mg}$ of memantine were given in single dose trials that showed mostly no or even negative effects in several cognitive domains. Nevertheless it is reasonable to assume that in healthy individuals, as it is with patients, these drugs would only show a potential effect after continuous intake [9].

\section{Histaminergics}

\section{Histamine $\mathrm{H} 3$ receptor inverse agonist/antagonist: pitolisant}

The third histamine receptor was discovered in 1983 by a traditional pharmacological approach, consisting of assessing the inhibitory effect of histamine on its own release from depolarized rat brain slices [147]. The same in vitro test was used to design, in 1987, the first highly selective and potent $\mathrm{H} 3$-autoreceptor ligands, the antagonist thioperamide and the agonist (R) alphamethylhistamine, which enhances and inhibits, respectively, the activity of histaminergic neurons in brain [148]. The use of these research tools was essential in establishing the main functions of cerebral histaminergic neurons, namely their role in maintenance of wakefulness, attention, learning and other cognitive processes. In 1990, the cloning of the gene of the H3-receptor, a member of the superfamily of heptahelical receptors coupled to $G$ proteins, paved the way to the demonstration of the high constitutive activity of the receptor, including its native form, and its participation in the tonic control of histamine release; it also facilitated the development of H3-receptor inverse agonist programs in many drug companies [149]. H3 antagonists increase the release of brain histamine, acetylcholine, noradrenaline, and dopamine. A number of $\mathrm{H} 3$ antagonists have advanced to the clinical research for the treatment of human cognitive disorders. Pitolisant, (1-(3-[3-(4chlorophenyl)propoxy]propyl)piperidine, hydrochloride) was the first histamine $\mathrm{H} 3$ receptor inverse agonist/antagonist to be introduced for the treatment of narcolepsy.

Pitolisant has been found to improve fear memories in mice [150]. No study of cognitive effects of pitolisant in healthy adults was published to date.

\section{H1 antagonist fexofenadine}

Fexofenadine (Allegra ${ }^{\circ}$, Fexidine ${ }^{\circ}$, Telfast, Fastofen', Tilfur', Vifas, Telfexo, Allerfexo ${ }^{\circ}$ ) is an anti-H1 antagonist that does not cross the blood-brain barrier contrary to previous anti-H1 drugs. It has been suggested that this drug may have a psychostimulant effect.

Five RCTs all reported no effect of fexofenadine (180-360 mg, single dose) administration on attention and vigilance in healthy subjects [25,151-154].

\section{Melatonininergics}

Melatonin (N-acetyl-5-methoxytryptamine) is a naturally occurring compound found in animals, plants, and microbes. In animals, circulating levels of the hormone melatonin vary in a daily cycle, thereby allowing the entrainment of the circadian rhythms of several biological functions. In humans, melatonin is produced by the pineal gland. Melatonin receptors appear to be important in mechanisms of learning and memory in mice [155]. Melatonin can initiate offline plastic changes underlying memory consolidation, an effect similar to the effect of sleep [156]. Products containing melatonin have been available over-the-counter in the United States since the mid-1990s. In many other countries, the purchase of melatonin requires a prescription. Agomelatine (Valdoxan", Melitor, Thymanax) is a melatoninergic antidepressant.

A single dose of $3 \mathrm{mg}$ melatonin specifically enhanced recognition memory accuracy of objects encoded under stress in 27 young volunteers versus 23 placebo controls [157].

\section{Non-Specified Neuroenhancers}

\section{Caffeine}

Caffeine, a methylxanthine, is the most widely consumed psychoactive substance in history [158]. Caffeine is an adenosine 
receptor antagonist that reduces inhibition of neural firing through an increased turnover of noradrenaline in the brain [159]. Unlike psychostimulant drugs, caffeine apparently only triggers a dopamine release in the prefrontal cortex, whereas a dopamine release in the ventral striatum does not occur [160]. Therefore, there is a neurobiologically definable difference leading to a lower addiction potential in comparison to psychostimulants that increase dopamine release in the ventral striatum such as amphetamines.

The widespread use of caffeine may be due in part to the perception that oral ingestion of the drug enhances performance and mood. However, the validity of the belief that caffeine can enhance human performances has been questioned, giving rise to debate. Surprisingly, we found no meta-analysis on caffeine cognitive effects in healthy adults. In a review, James et al. [161] concluded that appropriately controlled studies show that its apparent beneficial effects on performance and mood are almost wholly attributable to reversal of the withdrawal effects that occur after short periods of abstinence (e.g. overnight). It appears from a minority of low/non-consumer and longterm abstinence studies that there may be some modest improvement in mood, and perhaps performance, as an acute effect of caffeine when ingested in the absence of withdrawal. However, these effects are small and inconsequential compared with the effects attributable to withdrawal reversal. Crucially, these modest acute net effects also seem to be subjected to the development of tolerance when caffeine is repeatedly consumed.

\section{Glucocorticoids}

Tadeusz Reichstein together with Edward Calvin Kendall and Philip Showalter Hench were awarded the Nobel Prize for Physiology and Medicine in 1950 for their work on hormones of the adrenal cortex, which culminated in the isolation of cortisone. Cortisol, known more formally as hydrocortisone, is a steroid hormone, more specifically a glucocorticoid (GC), produced by the zona fasciculata of the adrenal cortex. It is released in response to stress and a low level of blood GC. Its primary functions are to increase blood sugar through gluconeogenesis, suppress the immune system, aid in fat, protein and carbohydrate metabolism, and also modify memory. GC are lipophilic hormones and can therefore readily pass the blood-brain barrier, where they influence numerous regions of the brain. GC receptors have been found in multiple areas of the brain, which are relevant to cognition, namely the hippocampus, the amygdala and the prefrontal cortex. The hippocampus is especially important for declarative or spatial memory, while the amygdala is critical for emotional memory as well as for the emotional modulation of other types of memory. The prefrontal cortex is crucial for working memory [162]. Cortisol may work with epinephrine to create memories of short-term emotional events. This is the proposed mechanism for storage of flash bulb memories, and may originate as a means to remember what to avoid in the future. Neuroactive steroids may also play a role in the modulation of memory by sigma receptors, and may modulate GABAA receptor function and various NMDA-evoked responses [163].

Human studies investigating the effects of acute GC treatment on memory have reported conflicting (enhancing as well as impairing) results. A meta-analysis of 16 studies $(\mathrm{N}=563$ healthy volunteers, mean age 24.23 years $(S D \pm 2.15)$ ), which experimentally investigated the acute impact of cortisol treatment (hydrocortisone) on human memory, revealed that the timing of GC application in the course of a study is a relevant variable, which explains a substantial amount of the significant heterogeneity within the effect sizes [164]. The used doses of hydrocortisone ranged from 5 to $100 \mathrm{mg}$ (median=25 mg; DM \pm 7.5). Retention interval ranged from 0 (immediate recall) up to $168 \mathrm{~h}$ (delayed recall). Four studies, which administered cortisol before retrieval, reported a significant decrease (average effect size of $\mathrm{d}=-0.49$ ) in memory performance. Twelve studies, which administered cortisol before learning, found on average no effect $(\mathrm{d}=0.08)$, but there was heterogeneity within these effect sizes. Further analysis on these experiments indicated that studies that administered cortisol in the morning found a significant memory impairment $(\mathrm{d}=-0.40)$, while studies conducted in the afternoon observed a small but significant memory enhancement $(d=0.22)$ [164]. A further recent RCT showed that $10 \mathrm{mg}$ single-dose hydrocortisone administration $45 \mathrm{~min}$ prior to the testing was associated with an enhancing effect on inhibitory performance in 54 healthy volunteers [165], working memory impairment in another sample of 56 healthy volunteers [166], and to fewer specific memories on the autobiographical memory testing [167]. Some positive effects of $10 \mathrm{mg}$ hydrocortisone on selective attention were also reported [168].

\section{Perspectives}

\section{Racetams}

The word "nootropic" was coined upon discovery of the effects of piracetam (pyrrolidone acetamide, Nootropil', Nootrop", Nootropil"), developed in the 1960s. Piracetam and piracetam-like molecules are thought to be neuroprotective agents with potential enhancement properties, possibly due to their common 2-oxopyrrolidine structure [11]. Ampakine activity has been established as one of the modes of action of the racetams, however these drugs have multiple modes of action and produce only weak AMPA receptor activation, and it is unclear how significant their ampakine actions are in producing their positive effects. Piracetam, aniracetam and oxiracetam are indicated in neurocognitive impairment and cognitive decline. Therapeutic applications of racetams are also reported [169].

Although animal studies suggest memory and wakefulness enhancement properties of several racetams [170-177], the effectiveness of piracetam or piracetam-like molecules was not explored in healthy adults to date. An explanation could be that all animal data focused on restoring age-impaired cognitive functions [11].

\section{Phosphodiesterase inhibitors}

The cyclic AMP/phosphokinase A/CREB pathway represents one of the main targets for the development of drugs for the treatment of patients with memory dysfunction [178]. Dopamine D1/D5 receptors are coupled to activation of the cAMP/ PKA/CREB pathway. Thus, D1/D5 receptor agonists may represent an effective pharmacological strategy to activate cAMP signaling in order to improve synaptic plasticity and memory [179]. Cyclic nucleotide phosphodiesterases (PDEs) are enzymes, which play an important role in the abovementioned intra-cellular signal transduction pathways. There are 11 families of PDEs (PDE1-PDE11) and most of these families have more than one gene product (e.g., PDE4A, PDE4B, PDE4C, PDE4D). In addition, each gene product may have multiple splice variants (e.g., PDE4D1-PDE4D9). In total, there are more than 100 specific human PDEs. Rolipram, which belongs to the above-mentioned racetams family, is a specific PDE4 inhibitor that has been shown to enhance both hippocampal long-term potentiation (LTP), memory transient 
wakefulness and neuroprotection in mice $[171,180]$ and LTP in humans $[181,182]$.

Beside the above mentioned open label studies that showed positive effects in LTP, no RCT explored the effectiveness of rolipram in healthy adults to date.

\section{Acetylsalicylic acid (ASPIRIN)}

Several studies reported that Nonsteroidal Anti-Inflammatory Drugs (NSAIDs) may reduce the risk of developing Alzheimer's disease, and that patients with rheumatoid arthritis, who often use NSAIDs, have a lower incidence of Alzheimer's disease [183,184]. Aspirin pre-treatment (600 mg, single dose) was found to improve working memory in healthy adults [185].

\section{Gaba $\alpha 5$ blockers}

GABAa5 blockers may provide a nootropic effect without the associated anxiogenic effects of general GABA inverse agonism $[186,187]$ but were not tested in healthy adults to date.

\section{Sigma agonists receptors}

Sigma agonists receptors increase acetylcholine release in both the hippocampus and the frontal cortex in rodent models [188] and may potentiate several NMDA-evoked responses in selected regions of the hippocampus [189], but were not tested in healthy adults to date.

\section{Discussion}

This synthetic, qualitative review presents evidence on cognitive enhancement effects of a number of drugs. The major findings are summarized in Table 1. Methylphenidate, amphetamines and modafinil (i.e. dopaminergics) showed some enhancing properties in memory and attention tasks. The same was the case for nicotine. On the contrary, no effects were found for serotoninergic, glutamatergic and cholinergic drugs. However, these substances were studied mostly in single-dose trials and it is probable that this design did not suit their pharmacological properties. Several other reasons for failing to find consistent results should also be considered. Samples in studies with healthy individuals are often much lower than in clinical trials; many of the studies reported here included less than 20 participants which is often not sufficient to detect a small effect. It is also often discussed whether cognitive tasks carried out in a neuropsychology laboratory are representative of real life [190]. The identification of cognitive enhancement effects should ideally include an optimization in terms of dose, individual genetic characteristics, baseline levels and the nature of the specific task. The effects on motivation, in addition to cognitive effects, also need to be investigated. We found that motivation was hardly evaluated in studies, although this dimension may be a particularly important modulator of the general effects of these substances when used as neuroenhancers. It is also shown that individual baseline characteristics seem to make a considerable difference to the outcomes of cognitive enhancement: positive effects seem in fact to be more prominent if the baseline performance of the individual is at the lower end of the normal distribution, which means that cognitive enhancers could potentially enable people with certain deficits to achieve a mean level of performance [191]. Some even postulate that this could be one (further) way to narrow the inequality of the "genetic lottery" [192]. However, concerns about coercion are also warranted. Regardless of their position in the normal distribution, healthy individuals might feel compelled to take cognitive enhancers because of real or perceived competitive pressure.

Very few data exist on students' perceived effects of cognitive enhancers on their cognitive and academic performance [193,194]. Although one of the reasons for taking prescription stimulants seems to be to improve academic performance, no long-term academic benefits from their use have been reported to date. The most commonly reported effect is short-term improved alertness and energy levels. Estimation of societal benefits and harms might require more information on effectiveness and prevalence [7]. Studies should differentiate between various types of drug use purposes and record prevalence and frequency data, as well as perceived efficacy. Use should also be correlated with other factors, such as sociodemographic indicators, academic performance, and illicit drug and alcohol use habits.

A widespread use of even some of the above reviewed substances does not seem warranted, not only because of the low level of evidence for a positive effect, but also because of the potential of side effects that were not presented in this paper. Acceptance for side effects would be lower in healthy individuals than in patients. For a meaningful use-risk analysis, long-term effects on the individuals and possibly on the societies should be considered. Since the majority of the studies that were performed until now were short-term and single-dose trials, no evidence-based statement can be made on long term effects and especially on reinforcing effects, dependence development, drug tolerance and long-term toxicity of these substances when used for cognitive enhancement purposes by healthy individuals.

Finally, most of the basic modes of action of the reviewed drugs have been elucidated, although this paper does not replace standard psychopharmacology textbooks to which the interested reader is encouraged to refer to [195]. For readers with little background in pharmacology in general and pharmacological cognitive enhancement in particular, it might seem counterintuitive that so many different substances with so diverse mode of actions are being reviewed. Our goal was to provide an overview of possible interventions and especially of interventions that have been discussed in the context of cognitive enhancement. Beside this, cognition is a broad concept and different aspects of cognition can be modulated through different neurotransmitter systems and hence through different substances. We are however fully aware that although some substances, such as amphetamines and methylphenidate, might be in use already, most of the substances reviewed here are not actually being used at all for enhancement purposes in everyday life and will probably never be used for that purpose in the future. For many of them, the high rate of side effects and/or the possibility of severe adverse effects will always be a limiting factor for their use, so that it is sheer hypothetical to consider them as conceivable neuroenhancers. It is only for the sake of completeness that we report results from RCTs on these drugs. We are especially aware that reviewing presumably enhancing effects of substances can induce a self-fulfilling prophecy, particularly if secondary literature overestimates reported positive effects. A recently published content analysis [196] of the coverage of one of the first studies of donepezil on healthy individuals [127] supports our concern: the media and bioethics literature made strong claims about donepezil being a cognitive enhancing drug. Enhancement language was used while reporting the results of the primary study and magnifying the perceived connection between these results and the cognitive enhancers debate that was alluded to in the primary study. In this review we could show to some extent the discrepancy between the 
Citation: Fond G, Micoulaud-Franchi JA, Macgregor A, Richieri R, Miot S, et al. (2015) Neuroenhancement in Healthy Adults, Part I: Pharmaceutical Cognitive Enhancement: A Systematic Review. J Clinic Res Bioeth 6: 213. doi:10.4172/2155-9627.1000213

Page 11 of 15

high expectations, as presented mainly through the mass media, and the actual effects of these drugs as found in RCTs.

\section{Conflicts of Interest}

All authors disclose no conflicts with the present work.

\section{References}

1. Giurgea C (1972) Pharmacology of integrative activity of the brain. Attempt at nootropic concept in psychopharmacology. Actual Pharmacol (Paris) 25: 115-156.

2. $\quad$ Eickenhorst P, Vitzthum K, Klapp BF, Groneberg D, Mache S (2012) Neuroenhancement among German university students: motives, expectations, and relationship with psychoactive lifestyle drugs. J Psychoactive Drugs 44: 418-427.

3. Heinz A, Kipke R, Heimann H, Wiesing U (2012) Cognitive neuroenhancement: false assumptions in the ethical debate. J Med Ethics 38: 372-375.

4. Wilens TE, Adler LA, Adams J, Sgambati S, Rotrosen J, et al. (2008) Misuse and diversion of stimulants prescribed for ADHD: a systematic review of the literature. J Am Acad Child Adolesc Psychiatry 47: 21-31.

5. Franke AG, Bagusat C, Dietz P, Hoffmann I, Simon P, et al. (2013) Use of illicit and prescription drugs for cognitive or mood enhancement among surgeons. BMC Med 11: 102.

6. Glannon W (2006) Psychopharmacology and memory. J Med Ethics 32: 74-78.

7. Forlini C, Hall W, Maxwell B, Outram SM, Reiner PB, et al. (2013) Navigating the enhancement landscape. Ethical issues in research on cognitive enhancers for healthy individuals. EMBO Rep 14: 123-128.

8. Repantis D, Schlattmann P, Laisney O, Heuser I (2010) Modafinil and methylphenidate for neuroenhancement in healthy individuals: A systematic review. Pharmacol Res 62: 187-206.

9. Repantis D, Laisney O, Heuser I (2010) Acetylcholinesterase inhibitors and memantine for neuroenhancement in healthy individuals: a systematic review. Pharmacol Res 61: 473-481.

10. Heishman SJ, Kleykamp BA, Singleton EG (2010) Meta-analysis of the acute effects of nicotine and smoking on human performance. Psychopharmacology (Berl) 210: 453-469.

11. Gualtieri F, Manetti D, Romanelli MN, Ghelardini C (2002) Design and study of piracetam-like nootropics, controversial members of the problematic class of cognition-enhancing drugs. Curr Pharm Des 8: 125-138.

12. Roeper J (2013) Dissecting the diversity of midbrain dopamine neurons. Trends Neurosci 36: 336-342.

13. Kintscher U (2012) Reuptake inhibitors of dopamine, noradrenaline, and serotonin. Handb Exp Pharmacol 2012: 339-347.

14. FDA, http://www.fda.org 2013.

15. Nandam LS, Hester R, Wagner J, Cummins TD, Garner K, et al. (2011) Methylphenidate but not atomoxetine or citalopram modulates inhibitory control and response time variability. Biol Psychiatry 69: 902-904.

16. Volkow ND, Fowler JS, Wang GJ, Telang F, Logan J, et al. (2008) Methylphenidate decreased the amount of glucose needed by the brain to perform a cognitive task. PLoS One 3: e2017.

17. Izquierdo I, Bevilaqua LR, Rossato JI, Lima RH, Medina JH et al. (2008) Age-dependent and age-independent human memory persistence is enhanced by delayed posttraining methylphenidate administration. Proc Natl Acad Sci USA 105: 19504-19507.

18. Dodds C, Müller U, Manly T (2009) Effects of psychostimulants on alertness and spatial bias in healthy participants. J Cogn Neurosci 21: 529-537.

19. Sevak RJ, Stoops WW, Hays LR, Rush CR (2009) Discriminative stimulus and subject-rated effects of methamphetamine, d-amphetamine, methylphenidate, and triazolam in methamphetamine-trained humans. J Pharmacol Exp Ther 328: 1007-1018.

20. Engert V, Joober R, Meaney MJ, Hellhammer DH, Pruessner JC (2009) Behavioral response to methylphenidate challenge: influence of early life parental care. Dev Psychobiol 51: 408-416.

21. Finke GR, Bozinovic F, Navarrete SA (2009) A mechanistic model to study the thermal ecology of a southeastern pacific dominant intertidal mussel and implications for climate change. Physiol Biochem Zool 82:303-313.

22. Kratz O, Diruf MS, Studer P, Gierow W, Buchmann J, et al. (2009) Effects of methylphenidate on motor system excitability in a response inhibition task. Behav Brain Funct 5: 12.

23. Schlösser RG, Nenadic I, Wagner G, Zysset S, Koch K, et al. (2009) Dopaminergic modulation of brain systems subserving decision making under uncertainty: a study with fMRI and methylphenidate challenge. Synapse 63: 429-442.

24. Studer P, Wangler S, Diruf MS, Kratz O, Moll GH, et al. (2010) ERP effects of methylphenidate and working memory load in healthy adults during a serial visual working memory task. Neurosci Lett 482: 172-176.

25. Theunissen EL, Elvira Jde L, van den Bergh D, Ramaekers JG (2009) Comparing the stimulant effects of the H1-antagonist fexofenadine with 2 psychostimulants, modafinil and methylphenidate. J Clin Psychopharmacol 29: 439-443.

26. Mereu M, Bonci A, Newman AH, Tanda G (2013) The neurobiology of modafinil as an enhancer of cognitive performance and a potential treatment for substance use disorders. Psychopharmacology (Berl) 229: 415-434.

27. Scammell TE, Estabrooke IV, McCarthy MT, Chemelli RM, Yanagisawa $\mathrm{M}$, et al. (2000) Hypothalamic arousal regions are activated during modafinil-induced wakefulness. J Neurosci 20: 8620-8628.

28. Minzenberg MJ, Carter CS (2008) Modafinil: a review of neurochemical actions and effects on cognition. Neuropsychopharmacology 33: 1477-1502.

29. Ballon JS, Feifel D (2006) A systematic review of modafinil: Potential clinical uses and mechanisms of action. J Clin Psychiatry 67: 554-566.

30. Joo EY, Tae WS, Jung KY, Hong SB (2008) Cerebral blood flow changes in man by wake-promoting drug, modafinil: a randomized double blind study. J Sleep Res 17: 82-88.

31. Minzenberg MJ, Watrous AJ, Yoon JH, Ursu S, Carter CS (2008) Modafinil shifts human locus coeruleus to low-tonic, high-phasic activity during functional MRI. Science 322: 1700-1702.

32. Rasetti R, Mattay VS, Stankevich B, Skjei K, Blasi G, et al. (2010) Modulatory effects of modafinil on neural circuits regulating emotion and cognition. Neuropsychopharmacology 35: 2101-2109.

33. Winder-Rhodes SE, Chamberlain SR, Idris MI, Robbins TW, Sahakian BJ, et al. (2010) Effects of modafinil and prazosin on cognitive and physiological functions in healthy volunteers. J Psychopharmacol 24: 1649-1657.

34. Kelley AM, Webb CM, Athy JR, Ley S, Gaydos S (2012) Cognition enhancement by modafinil: a meta-analysis. Aviat Space Environ Med 83: 685-690.

35. Torres B, Ruoho AE (2014) N-terminus regulation of VMAT2 mediates methamphetamine-stimulated efflux. Neuroscience 259: 194-202.

36. Wallace LJ (2012) Effects of amphetamine on subcellular distribution of dopamine and DOPAC. Synapse 66: 592-607.

37. Karoum F, Chrapusta SJ, Brinjak R, Hitri A, Wyatt RJ (1994) Regional effects of amphetamine, cocaine, nomifensine and GBR 12909 on the dynamics of dopamine release and metabolism in the rat brain. Br J Pharmacol 113: 1391-1399.

38. Micoulaud-Franchi JA, Fond G (2013) Cognitive enhancers consumption in medicine and pharmacy students: prevalences and motives. A crosssectional study. In press.

39. Weiss B, Laties VG (1962) Enhancement of human performance by caffeine and the amphetamines. Pharmacol Rev 14: 1-36. 
40. Zeeuws I, Deroost N, Soetens E (2010) Verbal memory improved by Damphetamine: influence of the testing effect. Hum Psychopharmacol 25: 377-387.

41. Zeeuws I, Deroost N, Soetens E (2010) Effect of an acute d-amphetamine administration on context information memory in healthy volunteers evidence from a source memory task. Hum Psychopharmacol 25 326-334.

42. Wardle MC, Hart AB, Palmer AA, de Wit H (2013) Does COMT genotype influence the effects of d-amphetamine on executive functioning? Genes Brain Behav 12: 13-20.

43. Whiting E, Chenery H, Chalk J, Darnell R, Copland D (2007) Dexamphetamine enhances explicit new word learning for novel objects. Int J Neuropsychopharmacol 10: 805-816.

44. Barch DM, Carter CS (2005) Amphetamine improves cognitive function in medicated individuals with schizophrenia and in healthy volunteers. Schizophr Res 77: 43-58.

45. Fillmore MT, Kelly TH, Martin CA (2005) Effects of d-amphetamine in human models of information processing and inhibitory control. Drug Alcohol Depend 77: 151-159.

46. de Wit H, Enggasser JL, Richards JB (2002) Acute administration of damphetamine decreases impulsivity in healthy volunteers. Neuropsychopharmacology 27: 813-825.

47. Ilieva I, Boland J, Farah MJ (2013) Objective and subjective cognitive enhancing effects of mixed amphetamine salts in healthy people. Neuropharmacology 64: 496-505.

48. Makris AP, Rush CR, Frederich RC, Taylor AC, Kelly TH (2007) Behavioral and subjective effects of d-amphetamine and modafinil in healthy adults. Exp Clin Psychopharmacol 15: 123-133.

49. Comer SD, Haney M, Foltin RW, Fischman MW (1996) Amphetamine self-administration by humans: modulation by contingencies associated with task performance. Psychopharmacology (Berl) 127: 39-46.

50. Kelly TH, Foltin RW, Fischman MW (1991) The effects of repeated amphetamine exposure on multiple measures of human behavior. Pharmacol Biochem Behav 38: 417-426.

51. Hughes FW, Forney RB (1964) Dextro-amphetamine, ethanol and dextro-amphetamine-ethanol combinations on performance of human subjects stressed with delayed audiotry feedback (DAF). Psychopharmacologia 6: 234-238.

52. Hurst PM, Weidner MF, Radlow R (1967) The effects of amphetamines upon judgments and decisions. Psychopharmacologia 11: 397-404.

53. Soetens E, Casaer S, D'Hooge R, Hueting JE (1995) Effect of amphetamine on long-term retention of verbal material. Psychopharmacology (Berl) 119: 155-162.

54. Kumari V, Corr PJ, Mulligan OF, Cotter PA, Checkley SA, et al. (1997) Effects of acute administration of d-amphetamine and haloperidol on procedural learning in man. Psychopharmacology (Berl) 129: 271-276.

55. Silber BY, Croft RJ, Papafotiou K, Stough C (2006) The acute effects of damphetamine and methamphetamine on attention and psychomotor performance. Psychopharmacology (Berl) 187: 154-169.

56. Allman AA, Benkelfat C, Durand F, Sibon I, Dagher A, et al. (2010) Effect of D-amphetamine on inhibition and motor planning as a function of baseline performance. Psychopharmacology (Berl) 211: 423-433.

57. Ballard ME, Gallo DA, de Wit H (2012) Psychoactive drugs and false memory: comparison of dextroamphetamine and $\hat{\mathrm{I}}^{\prime}-9$ tetrahydrocannabinol on false recognition. Psychopharmacology (Berl) 219: 15-24.

58. Silber BY, Croft RJ, Downey LA, Camfield DA, Papafotiou K, et al. (2012) The effect of d,l-methamphetamine on simulated driving performance. Psychopharmacology (Berl) 219: 1081-1087.

59. Hjälmdahl M, Vadeby A, Forsman A, Fors C, Ceder G, et al. (2012) Effects of d-amphetamine on simulated driving performance before and after sleep deprivation. Psychopharmacology (Berl) 222: 401-411.

60. Kirkpatrick MG, Gunderson EW, Perez AY, Haney M, Foltin RW, et al. (2012) A direct comparison of the behavioral and physiological effects of methamphetamine and 3,4-methylenedioxymethamphetamine (MDMA) in humans. Psychopharmacology (Berl) 219: 109-122.

61. Breitenstein C, Wailke S, Bushuven S, Kamping S, Zwitserlood P, et al. (2004) D-amphetamine boosts language learning independent of its cardiovascular and motor arousing effects. Neuropsychopharmacology 29: $1704-1714$

62. Apud JA, Mattay V, Chen J, Kolachana BS, Callicott JH (2007) Tolcapone improves cognition and cortical information processing in normal human subjects. Neuropsychopharmacology 32:1011-1120.

63. Roussos P, Giakoumaki SG, Bitsios P (2009) Tolcapone effects on gating, working memory, and mood interact with the synonymous catechol-Omethyltransferase rs $4818 \mathrm{c} / \mathrm{g}$ polymorphism. Biol Psychiatry 66: 997-1004.

64. Magalona SC, Rasetti R, Chen J, Chen Q, Gold I et al. (2013) Effect of tolcapone on brain activity during a variable attentional control task: a double-blind, placebo-controlled, counter-balanced trial in healthy volunteers. CNS Drugs 27: 663-673.

65. Knecht S, Breitenstein C, Bushuven S, Wailke S, Kamping S, et al. (2004) Levodopa: faster and better word learning in normal humans. Ann Neurol 56: 20-26.

66. Andreou C, Moritz S, Veith K, Veckenstedt R, Naber D (2014) Dopaminergic modulation of probabilistic reasoning and overconfidence in errors: a double-blind study. Schizophr Bull 40: 558-565.

67. Schnider A, Guggisberg A, Nahum L, Gabriel D, Morand S (2010) Dopaminergic modulation of rapid reality adaptation in thinking. Neuroscience 167: 583-587.

68. Flöel A, Breitenstein C, Hummel F, Celnik P, Gingert C, et al. (2005) Dopaminergic influences on formation of a motor memory. Ann Neurol 58: 121-130.

69. Floel A, Vomhof P, Lorenzen A, Roesser N, Breitenstein C, et al. (2008) Levodopa improves skilled hand functions in the elderly. Eur J Neurosci 27: 1301-1307.

70. Oranje B, Gispen-de Wied CC, Westenberg HG, Kemner C, Verbaten $\mathrm{MN}$, et al. (2006) No effects of 1-dopa and bromocriptine on psychophysiological parameters of human selective attention. J Psychopharmacol 20: 789-798.

71. Floel A, Garraux G, Xu B, Breitenstein C, Knecht S, et al. (2008) Levodopa increases memory encoding and dopamine release in the striatum in the elderly. Neurobiol Aging 29: 267-279.

72. Micallef J, Rey M, Eusebio A, Audebert C, Rouby F, et al. (2009) Antiparkinsonian drug-induced sleepiness: a double-blind placebocontrolled study of L-dopa, bromocriptine and pramipexole in healthy subjects. Br J Clin Pharmacol 67: 333-340.

73. Pizzagalli DA, Evins AE, Schetter EC, Frank MJ, Pajtas PE, et al. (2008) Single dose of a dopamine agonist impairs reinforcement learning in humans: behavioral evidence from a laboratory-based measure of reward responsiveness. Psychopharmacology (Berl) 196:221-232.

74. Jäkälä P, Sirviö J, Riekkinen M, Koivisto E, Kejonen K, et al. (1999) Guanfacine and clonidine, alpha 2-agonists, improve paired associates learning, but not delayed matching to sample, in humans. Neuropsychopharmacology 20: 119-130.

75. Tiplady B, Bowness E, Stien L, Drummond G (2005) Selective effects of clonidine and temazepam on attention and memory. J Psychopharmacol 19: 259-265.

76. Müller U, Clark L, Lam ML, Moore RM, Murphy CL, et al. (2005) Lack of effects of guanfacine on executive and memory functions in healthy male volunteers. Psychopharmacology (Berl) 182: 205-213.

77. Schulz KP, Clerkin SM, Fan J, Halperin JM, Newcorn JH (2013) Guanfacine modulates the influence of emotional cues on prefrontal cortex activation for cognitive control. Psychopharmacology (Berl) 226: 261-271.

78. Bymaster FP, Katner JS, Nelson DL, Hemrick-Luecke SK, Threlkeld PG et al. (2002) Atomoxetine increases extracellular levels of norepinephrine and dopamine in prefrontal cortex of rat: a potential mechanism for efficacy in attention deficit/hyperactivity disorder. Neuropsychopharmacology 27:699-711. 
79. Plewnia C, Hoppe J, Gerloff C (2006) No effects of enhanced central norepinephrine on finger-sequence learning and attention. Psychopharmacology (Berl) 187: 260-265.

80. Papps BP, Shajahan PM, Ebmeier KP, O'Carroll RE (2002) The effects of noradrenergic re-uptake inhibition on memory encoding in man. Psychopharmacology (Berl) 159: 311-318.

81. Siepmann M, Mück-Weymann M, Joraschky P, Kirch W (2001) The effects of reboxetine on autonomic and cognitive functions in healthy volunteers. Psychopharmacology (Berl) 157: 202-207.

82. Chamberlain SR, Müller U, Blackwell AD, Clark L, Robbins TW, et al. (2006) Neurochemical modulation of response inhibition and probabilistic learning in humans. Science 311: 861-863.

83. Seyedabadi M, Fakhfouri G, Ramezani V, Mehr SE, Rahimian R (2014) The role of serotonin in memory: interactions with neurotransmitters and downstream signaling. Exp Brain Res 232: 723-738.

84. Repantis D, Schlattmann P, Laisney O, Heuser I (2009) Antidepressants for neuroenhancement in healthy individuals: a systematic review. Poiesis \& Praxis 6:139-174.

85. Brannan T, Prikhojan A, Martínez-Tica J, Yahr MD (1995) In vivo comparison of the effects of inhibition of MAO-A versus MAO-B on striatal L-DOPA and dopamine metabolism. J Neural Transm Park Dis Dement Sect 10: 79-89.

86. Dingemanse J, Berlin I, Payan C, Thiede HM, Puech AJ (1992) Comparative investigation of the effect of moclobemide and toloxatone on monoamine oxidase activity and psychometric performance in healthy subjects. Psychopharmacology (Berl) 106 Suppl: S68-70.

87. Siepmann M, Handel J, Mueck-Weymann M, Kirch W (2004) The effects of moclobemide on autonomic and cognitive functions in healthy volunteers. Pharmacopsychiatry 37: 81-87.

88. Warot D, Berlin I, Patat A, Durrieu G, Zieleniuk I, et al. (1996) Effects of befloxatone, a reversible selective monoamine oxidase- $A$ inhibitor, on psychomotor function and memory in healthy subjects. J Clin Pharmacol 36: 942-950.

89. Schwartz BL, Hashtroudi S, Herting RL, Handerson H, Deutsch SI (1991) Glycine prodrug facilitates memory retrieval in humans. Neurology 41 : 1341-1343.

90. Camp-Bruno JA, Herting RL (1994) Cognitive effects of milacemide and methylphenidate in healthy young adults. Psychopharmacology (Berl) 115: 46-52.

91. Lapinsky DJ, Aggarwal S, Nolan TL, Surratt CK, Lever JR, et al. (2012) ( \pm )-2-(N-tert-Butylamino)-3'-[(125)I]-iodo-4'-azidopropiophenone: a dopamine transporter and nicotinic acetylcholine receptor photoaffinity ligand based on bupropion (Wellbutrin, Zyban). Bioorg Med Chem Lett 22: 523-526.

92. Carvalho AF, Köhler CA, Cruz EP, Stürmer PL, Reichman BP, et al. (2006) Acute treatment with the antidepressants bupropion and sertraline do not influence memory retrieval in man. Eur Arch Psychiatry Clin Neurosci 256: 320-325.

93. Peck AW, Bye CE, Clubley M, Henson T, Riddington C (1979) A comparison of bupropion hydrochloride with dexamphetamine and amitriptyline in healthy subjects. Br J Clin Pharmacol 7: 469-478.

94. Peck AW, Hamilton M (1983) Psychopharmacology of bupropion in normal volunteers. J Clin Psychiatry 44: 202-205.

95. Gobbi G, Slater S, Boucher N, Debonnel G, Blier P (2003) Neurochemical and psychotropic effects of bupropion in healthy male subjects. J Clin Psychopharmacol 23: 233-239.

96. Acheson A, de Wit H (2008) Bupropion improves attention but does not affect impulsive behavior in healthy young adults. Exp Clin Psychopharmacol 16: 113-123.

97. Chevassus H, Farret A, Gagnol JP, Ponçon CA, Costa F, et al. (2013) Psychological and physiological effects of bupropion compared to methylphenidate after prolonged administration in healthy volunteers (NCT00285155). Eur J Clin Pharmacol 69: 779-787.
98. Nowakowska E, Kus K, Chodera A, Rybakowski J (2000) Behavioural effects of fluoxetine and tianeptine, two antidepressants with opposite action mechanisms, in rats. Arzneimittelforschung 50: 5-10.

99. McEwen BS, Chattarji S, Diamond DM, Jay TM, Reagan LP, et al. (2010) The neurobiological properties of tianeptine (Stablon): from monoamine hypothesis to glutamatergic modulation. Mol Psychiatry 15: 237-249.

100. Invernizzi R, Pozzi L, Garattini S, Samanin R (1992) Tianeptine increases the extracellular concentrations of dopamine in the nucleus accumbens by a serotonin-independent mechanism. Neuropharmacology 31:221-227.

101. Wlaź P, Kasperek R, Wlaź A, Szumiło M, Wróbel A, et al. (2011) NMDA and AMPA receptors are involved in the antidepressant-like activity of tianeptine in the forced swim test in mice. Pharmacol Rep 63: 1526-1532.

102. Invernizzi G, Aguglia E, Bertolino A, Casacchia M, Ciani N, et al. (1994) The efficacy and safety of tianeptine in the treatment of depressive disorder: results of a controlled double-blind multicentre study vs. amitriptyline. Neuropsychobiology 30: 85-93.

103. Bernard K, Penelaud PF, Mocaër E, Donazzolo Y (2011) Absence of psychostimulant effects of a supratherapeutic dose of tianeptine: a placebo-controlled study versus methylphenidate in young healthy volunteers. J Clin Psychopharmacol 31: 441-448.

104. Woolf NJ (1991) Cholinergic systems in mammalian brain and spinal cord. Prog Neurobiol 37: 475-524.

105. Everitt BJ, Robbins TW (1997) Central cholinergic systems and cognition. Annu Rev Psychol 48: 649-684.

106. Graef S, Schönknecht P, Sabri O, Hegerl U (2011) Cholinergic receptor subtypes and their role in cognition, emotion, and vigilance control: an overview of preclinical and clinical findings. Psychopharmacology (Berl) 215: 205-229.

107. Levin ED, McClernon FJ, Rezvani AH (2006) Rezvani, Nicotinic effects on cognitive function: behavioral characterization, pharmacological specification, and anatomic localization. Psychopharmacology (Berl) 184: 523-539.

108. Son JH, Winzer-Serhan UH (2008) Expression of neuronal nicotinic acetylcholine receptor subunit mRNAs in rat hippocampal GABAergic interneurons. J Comp Neurol 511: 286-299.

109. Biton B, Bergis OE, Galli F, Nedelec A, Lochead AW et al. (2007) SSR180711, a novel selective alpha7 nicotinic receptor partial agonist: (1) binding and functional profile. Neuropsychopharmacology 32:1-16.

110. Yakel JL (2013) Cholinergic receptors: functional role of nicotinic ACh receptors in brain circuits and disease. Pflugers Arch 465: 441-450.

111. Bartus RT, Dean RL 3rd, Beer B, Lippa AS (1982) The cholinergic hypothesis of geriatric memory dysfunction. Science 217: 408-414.

112. Froestl W, Muhs A, Pfeifer A (2012) Cognitive enhancers (nootropics). Part 1: drugs interacting with receptors. J Alzheimers Dis 32: 793-887.

113. Levin ED, Rose JE (1995) Acute and chronic nicotinic interactions with dopamine systems and working memory performance. Ann N Y Acad Sci 757: 245-252.

114. Sherwood N (1995) Effects of cigarette smoking on performance in a simulated driving task. Neuropsychobiology 32: 161-165.

115. Mumenthaler MS, Taylor JL, O'Hara R, Yesavage JA (1998) Influence of nicotine on simulator flight performance in non-smokers. Psychopharmacology (Berl) 140: 38-41.

116. Mihalak KB, Carroll FI, Luetje CW (2006) Varenicline is a partial agonist at alpha4beta2 and a full agonist at alpha7 neuronal nicotinic receptors. Mol Pharmacol 70: 801-805.

117. Hutchison CW, Nathan PJ, Mrazek L, Stough C (2001) Cholinergic modulation of speed of early information processing: the effect of donepezil on inspection time. Psychopharmacology (Berl) 155: 440-442.

118. Zaninotto AL, Bueno OF, Pradella-Hallinan M, Tufik S, Rusted J, et al. (2009) Acute cognitive effects of donepezil in young, healthy volunteers. Hum Psychopharmacol 24: 453-464.

119. Snyder PJ, Bednar MM, Cromer JR, Maruff P (2005) Reversal of scopolamine-induced deficits with a single dose of donepezil, an acetylcholinesterase inhibitor. Alzheimers Dement 1: 126-135. 
Citation: Fond G, Micoulaud-Franchi JA, Macgregor A, Richieri R, Miot S, et al. (2015) Neuroenhancement in Healthy Adults, Part I: Pharmaceutical Cognitive Enhancement: A Systematic Review. J Clinic Res Bioeth 6: 213. doi:10.4172/2155-9627.1000213

Page 14 of 15

120. Rokem A, Silver MA (2010) Cholinergic enhancement augments magnitude and specificity of visual perceptual learning in healthy humans. Curr Biol 20: 1723-1728.

121. Hornung OP, Regen F, Danker-Hopfe H, Schredl M, Heuser I (2007) The relationship between REM sleep and memory consolidation in old age and effects of cholinergic medication. Biol Psychiatry 61: 750-757.

122. Ginani GE, Tufik S, Bueno OF, Pradella-Hallinan M, Rusted J, et al. (2011) Acute effects of donepezil in healthy young adults underline the fractionation of executive functioning. J Psychopharmacol 25: 1508-1516.

123. Rokem A, Landau AN, Garg D, Prinzmetal W, Silver MA (2010) Cholinergic enhancement increases the effects of voluntary attention but does not affect involuntary attention. Neuropsychopharmacology 35: 2538-2544.

124. Nathan PJ, Baker A, Carr E, Earle J, Jones M, et al. (2001) Cholinergic modulation of cognitive function in healthy subjects: acute effects of donepezil, a cholinesterase inhibitor. Hum Psychopharmacol 16: 481-483.

125. Ashare RL, Ray R, Lerman C, Strasser AA (2012) Cognitive effects of the acetylcholinesterase inhibitor, donepezil, in healthy, non-treatment seeking smokers: a pilot feasibility study. Drug Alcohol Depend 126: 263-267.

126. Grön G, Kirstein M, Thielscher A, Riepe MW, Spitzer M (2005) Cholinergic enhancement of episodic memory in healthy young adults. Psychopharmacology (Berl) 182: 170-179.

127. Yesavage JA, Mumenthaler MS, Taylor JL, Friedman L, O'Hara R, et al. (2002) Donepezil and flight simulator performance: effects on retention of complex skills. Neurology 59: 123-125.

128. Rapoport MJ, Weaver B, Kiss A, Zucchero Sarracini C, Moller H, et al. (2011) The effects of donepezil on computer-simulated driving ability among healthy older adults: a pilot study. J Clin Psychopharmacol 31: 587-592.

129. Beglinger LJ, Gaydos BL, Kareken DA, Tangphao-Daniels O, Siemers ER, et al. (2004) Neuropsychological test performance in healthy volunteers before and after donepezil administration. J Psychopharmacol 18: 102-108.

130. Beglinger LJ, Tangphao-Daniels O, Kareken DA, Zhang L, Mohs R, et al. (2005) Neuropsychological test performance in healthy elderly volunteers before and after donepezil administration: a randomized, controlled study. J Clin Psychopharmacol 25: 159-165.

131. Balsters JH, O'Connell RG, Martin MP, Galli A, Cassidy SM, et al. (2011) Donepezil impairs memory in healthy older subjects: behavioural, EEG and simultaneous EEG/fMRI biomarkers. PLoS One 6: e24126.

132. Furey ML, Pietrini P, Haxby JV, Alexander GE, Lee HC, et al. (1997) Cholinergic stimulation alters performance and task-specific regional cerebral blood flow during working memory. Proc Natl Acad Sci USA 94: 6512-6516.

133. Kirrane RM, Mitropoulou V, Nunn M, Silverman J, Siever LJ (2001) Physostigmine and cognition in schizotypal personality disorder. Schizophr Res 48: 1-5.

134. Davis KL, Hollister LE, Overall J, Johnson A, Train K (1976) Physostigmine: effects on cognition and affect in normal subjects. Psychopharmacology (Berl) 51: 23-27.

135. Wezenberg E, Verkes RJ, Sabbe BG, Ruigt GS, Hulstijn W (2005) Modulation of memory and visuospatial processes by biperiden and rivastigmine in elderly healthy subjects. Psychopharmacology (Berl) 181: 582-594.

136. Pomara N, Yi L, Belzer K, Facelle TM, Willoughby LM, et al. (2010) Retrograde facilitation of verbal memory by trihexyphenidyl in healthy elderly with and without the APOE epsilon4 allele. Eur Neuropsychopharmacol 20: 467-472.

137. Guthrie SK, Manzey L, Scott D, Giordani B, Tandon R (2000) Comparison of central and peripheral pharmacologic effects of biperiden and trihexyphenidyl in human volunteers. J Clin Psychopharmacol 20: 77-83.
138. Wang M, Wong AH, Liu F (2012) Interactions between NMDA and dopamine receptors: a potential therapeutic target. Brain Res 1476: 154-163.

139. Molas S, Dierssen M2 (2014) The role of nicotinic receptors in shaping and functioning of the glutamatergic system: a window into cognitive pathology. Neurosci Biobehav Rev 46 Pt 2: 315-325.

140. Artola A, Singer W (1987) Long-term potentiation and NMDA receptors in rat visual cortex. Nature 330: 649-652.

141. Baudry M, Kramar E, Xu X, Zadran H, Moreno S, et al. (2012) Ampakines promote spine actin polymerization, long-term potentiation, and learning in a mouse model of Angelman syndrome. Neurobiol Dis 47: 210-215.

142. Wezenberg E, Verkes RJ, Ruigt GS, Hulstijn W, Sabbe BG (2007) Acute effects of the ampakine farampator on memory and information processing in healthy elderly volunteers. Neuropsychopharmacology 32 : 1272-1283.

143. Lynch G, Kessler M, Rogers G, Ambros-Ingerson J, Granger R, et al. (1996) Psychological effects of a drug that facilitates brain AMPA receptors. Int Clin Psychopharmacol 11: 13-19.

144. Lynch G, Granger R, Ambros-Ingerson J, Davis CM, Kessler M, et al. (1997) Evidence that a positive modulator of AMPA-type glutamate receptors improves delayed recall in aged humans. Exp Neurol 145: 89-92.

145. Ingvar M, Ambros-Ingerson J, Davis M, Granger R, Kessler M, et al. (1997) Enhancement by an ampakine of memory encoding in humans. Exp Neurol 146: 553-559.

146. Schneider LS, Dagerman KS, Higgins JP, McShane R (2011) Lack of evidence for the efficacy of memantine in mild Alzheimer disease. Arch Neurol 68: 991-998.

147. Arrang JM, Garbarg M, Schwartz JC (1983) Auto-inhibition of brain histamine release mediated by a novel class (H3) of histamine receptor. Nature 302: 832-837.

148. Arrang JM, Garbarg M, Lancelot JC, Lecomte JM, Pollard H, et al. (1987) Highly potent and selective ligands for histamine H3-receptors. Nature 327: $117-123$.

149. Schwartz JC (2011) The histamine H3 receptor: from discovery to clinical trials with pitolisant. Br J Pharmacol 163: 713-721.

150. Brabant C, Charlier Y, Tirelli E (2013) The histamine Hâ,f-receptor inverse agonist pitolisant improves fear memory in mice. Behav Brain Res 243: 199-204.

151. Vacchiano C, Moore J, Rice GM, Crawley G (2008) Fexofenadine effects on cognitive performance in aviators at ground level and simulated altitude. Aviat Space Environ Med 79: 754-760.

152. Theunissen EL, Jonkman LM, Kuypers KP, Ramaekers JG (2006) A combined neurophysiological and behavioural study into the stimulating effects of fexofenadine on performance. J Psychopharmacol 20: 496-505.

153. Mansfield L, Mendoza C, Flores J, Meeves SG (2003) Effects of fexofenadine, diphenhydramine, and placebo on performance of the test of variables of attention (TOVA). Ann Allergy Asthma Immunol 90: 554-559.

154. Bower EA, Moore JL, Moss M, Selby KA, Austin M, et al. (2003) The effects of single-dose fexofenadine, diphenhydramine, and placebo on cognitive performance in flight personnel. Aviat Space Environ Med 74: $145-152$.

155. Larson J, Jessen RE, Uz T, Arslan AD, Kurtuncu M, et al. (2006) Impaired hippocampal long-term potentiation in melatonin MT2 receptordeficient mice. Neurosci Lett 393: 23-26.

156. Gorfine T, Yeshurun Y, Zisapel N (2007) Nap and melatonin-induced changes in hippocampal activation and their role in verbal memory consolidation. J Pineal Res 43: 336-342.

157. Rimmele U, Spillmann M, Bärtschi C, Wolf OT, Weber CS, et al. (2009) Melatonin improves memory acquisition under stress independent of stress hormone release. Psychopharmacology (Berl) 202: 663-672.

158. James JE (1997) Is habitual caffeine use a preventable cardiovascular risk factor? Lancet 349: 279-281. 
Citation: Fond G, Micoulaud-Franchi JA, Macgregor A, Richieri R, Miot S, et al. (2015) Neuroenhancement in Healthy Adults, Part I: Pharmaceutical Cognitive Enhancement: A Systematic Review. J Clinic Res Bioeth 6: 213. doi:10.4172/2155-9627.1000213

Page 15 of 15

159. Tofovic SP, Kusaka H, Pfeifer CA, Jackson EK (1996) Central effects of caffeine on renal renin secretion and norepinephrine spillover. J Cardiovasc Pharmacol 28: 302-313.

160. Acquas E, Tanda G, Di Chiara G (2002) Differential effects of caffeine on dopamine and acetylcholine transmission in brain areas of drug-naive and caffeine-pretreated rats. Neuropsychopharmacology 27: 182-193.

161. James JE, Gregg ME, Kane M, Harte F (2005) Dietary caffeine, performance and mood: enhancing and restorative effects after controlling for withdrawal reversal. Neuropsychobiology 52: 1-10.

162. Wolf OT (2003) HPA axis and memory. Best Pract Res Clin Endocrinol Metab 17: 287-299.

163. Maurice T, Phan VL, Urani A, Kamei H, Noda Y, et al. (1999) Neuroactive neurosteroids as endogenous effectors for the sigmal (sigma1) receptor: pharmacological evidence and therapeutic opportunities. Jpn J Pharmacol 81: 125-155.

164. Het S, Ramlow G, Wolf OT (2005) A meta-analytic review of the effects of acute cortisol administration on human memory. Psychoneuroendocrinology 30: 771-784.

165. Schlosser N, Wolf OT, Fernando SC, Terfehr K, Otte C, et al. (2013) Effects of acute cortisol administration on response inhibition in patients with major depression and healthy controls. Psychiatry Res 209: 439-446.

166. Terfehr K, Wolf OT, Schlosser N, Fernando SC, Otte C, et al. (2011) Hydrocortisone impairs working memory in healthy humans, but not in patients with major depressive disorder. Psychopharmacology (Berl) 215: 71-79.

167. Schlosser N, Wolf OT, Fernando SC, Riedesel K, Otte C (2010) Effects of acute cortisol administration on autobiographical memory in patients with major depression and healthy controls. Psychoneuroendocrinology 35: 316-320.

168. Henckens MJ, van Wingen GA, Joëls M, Fernández G (2012) Timedependent effects of cortisol on selective attention and emotional interference: a functional MRI study. Front Integr Neurosci 6: 66.

169. Malykh AG, Sadaie MR (2010) Piracetam and piracetam-like drugs: from basic science to novel clinical applications to CNS disorders. Drugs 70: 287-312.

170. Scheuer K, Rostock A, Bartsch R, Müller WE (1999) Piracetam improves cognitive performance by restoring neurochemical deficits of the aged rat brain. Pharmacopsychiatry 32 Suppl 1: 10-16.

171. Barad M, Bourtchouladze R, Winder DG, Golan H, Kandel E (1998) Rolipram, a type IV-specific phosphodiesterase inhibitor, facilitates the establishment of long-lasting long-term potentiation and improves memory. Proc Natl Acad Sci USA 95: 15020-15025.

172. Samartgis JR, Schachte L, Hazi A, Crowe SF (2012) Piracetam, an AMPAkine drug, facilitates memory consolidation in the day-old chick. Pharmacol Biochem Behav 103: 353-358.

173. Grossman L, Stewart A, Gaikwad S, Utterback E, Wu N, et al. (2011) Effects of piracetam on behavior and memory in adult zebrafish. Brain Res Bull 85: 58-63.

174. Trofimov SS, Voronina TA, Guzevatykh LS (2005) Early postnatal effects of noopept and piracetam on declarative and procedural memory of adult male and female rats. Bull Exp Biol Med 139: 683-687.

175. Lelkes Z, Alföldi P, Erdos A, Benedek G (1998) Rolipram, an antidepressant that increases the availability of cAMP, transiently enhances wakefulness in rats. Pharmacol Biochem Behav 60: 835-839.

176. Mondadori C, Classen W, Borkowski J, Ducret T, Buerki H, et al. (1986) Effects of oxiracetam on learning and memory in animals: comparison with piracetam. Clin Neuropharmacol 9 Suppl 3: S27-38.

177. Tushmalova NA, Pragina LL, Inozemtsev AN, Gumargalieva KZ, Solov'ev AG, et al. (1995) [Effect of low doses of piracetam on conditional reflex memory in rats]. Biull Eksp Biol Med 120: 60-61.
178. Tully T, Bourtchouladze R, Scott R, Tallman J (2003) Targeting the CREB pathway for memory enhancers. Nat Rev Drug Discov 2: 267-277.

179. Otmakhova NA, Lisman JE (1998) D1/D5 dopamine receptors inhibit depotentiation at CA1 synapses via cAMP-dependent mechanism. J Neurosci 18: 1270-1279.

180. Block F, Schmidt W, Nolden-Koch M, Schwarz M (2001) Rolipram reduces excitotoxic neuronal damage. Neuroreport 12: 1507-1511.

181. Rutten K, Prickaerts J, Hendrix M, van der Staay FJ, Sik A et al. (2007) Time-dependent involvement of cAMP and cGMP in consolidation of object memory: studies using selective phosphodiesterase type 2, 4 and 5 inhibitors. Eur J Pharmacol 558:107-112.

182. Rutten K, Prickaerts J, Blokland A (2006) Rolipram reverses scopolamine-induced and time-dependent memory deficits in object recognition by different mechanisms of action. Neurobiol Learn Mem 85:132-138.

183. McGeer PL, Schulzer M, McGeer EG (1996) Arthritis and antiinflammatory agents as possible protective factors for Alzheimer's disease: a review of 17 epidemiologic studies. Neurology 47: 425-432.

184. McGeer PL, McGeer E, Rogers J, Sibley J (1990) Anti-inflammatory drugs and Alzheimer disease. Lancet 335: 1037.

185. Watson S, Horton K, Bulmer S, Carlile J, Corcoran C, et al. (2009) Effect of aspirin on hypothalamic-pituitary-adrenal function and on neuropsychological performance in healthy adults: a pilot study. Psychopharmacology (Berl) 205: 151-155.

186. Milić M, Timić T, Joksimović S, Biawat P, Rallapalli S et al. (2013) PWZ-029, an inverse agonist selective for alpha(5) GABAA receptors, improves object recognition, but not water-maze memory in normal and scopolamine-treated rats. Behav Brain Res 241:206-213.

187. Koh MT, Rosenzweig-Lipson S, Gallagher M (2013) Selective GABA(A) a5 positive allosteric modulators improve cognitive function in aged rats with memory impairment. Neuropharmacology 64:145-152.

188. Matsuno K, Senda T, Kobayashi T, Mita S (1995) Involvement of sigma 1 receptor in (+)-N-allylnormetazocine-stimulated hippocampal cholinergic functions in rats. Brain Res 690: 200-206.

189. Hong W, Werling LL (2000) Evidence that the sigma(1) receptor is not directly coupled to G proteins. Eur J Pharmacol 408: 117-125.

190. Smith ME, Farah MJ (2011) Are prescription stimulants "smart pills"? The epidemiology and cognitive neuroscience of prescription stimulant use by normal healthy individuals. Psychol Bull 137: 717-741.

191. Mattay VS, Callicott JH, Bertolino A, Heaton I, Frank JA, et al. (2000) Effects of dextroamphetamine on cognitive performance and cortical activation. Neuroimage 12: 268-275.

192. Harris J (2011) Moral enhancement and freedom. Bioethics 25: 102-111.

193. Micoulaud-Franchi JA, Vion-Dury J, Lancon C (2012) Neuroenhancement in healthy subject? A French case study. Therapie 67: 213-221.

194. Micoulaud-Franchi JA, MacGregor A, Fond G (2014) A preliminary study on cognitive enhancer consumption behaviors and motives of French Medicine and Pharmacology students. Eur Rev Med Pharmacol Sci 18: 1875-1878.

195. Sadock BJ, Sadock VA, Ruiz P (2009) Kaplan and Sadock's Comprehensive Textbook of Psychiatry. Wolters Kluwer, Philadelphia, USA.

196. Wade L, Forlini C, Racine E (2014) Generating genius: how an Alzheimer's drug became considered a 'cognitive enhancer' for healthy individuals. BMC Med Ethics 15: 37. 